\title{
Economic and Phosphorus-Related Effects of Precision Feeding and Forage Management at a Farm Scale
}

\author{
L. T. Ghebremichael, ${ }^{\star 1}$ P. E. Cerosaletti,† T. L. Veith,‡ C. A. Rotz,ł J. M. Hamlett, ${ }^{\star}$ and W. J. Gburekł \\ *Agricultural and Biological Engineering, Pennsylvania State University, University Park 16802 \\ †Cornell Cooperative Extension of Delaware County, Hamden, NY 13782 \\ ¥USDA Pasture Systems and Watershed Management Research Unit, University Park, PA 16802
}

\section{ABSTRACT}

Structural best management practices were implemented throughout the Cannonsville Reservoir Watershed (CRW) in an effort to reduce P losses to the reservoir. Yet long-term water quality control efforts within CRW are hindered by continuous $\mathrm{P}$ build-up in the soils resulting from dairy farm $\mathrm{P}$ imports exceeding exports. Addressing the $\mathrm{P}$ imbalance problems and maintaining economic viability of the farms requires a system-level redesign of farm management. One possible innovative strategy, precision feed management (PFM), reduces soil-P build-up by limiting feed and fertilizer purchases, and increasing high-quality homegrown forage production. This study applied the integrated farm system model (IFSM) to 2 CRW dairy farms to quantify the benefits of a PFM farm planning strategy in controlling $\mathrm{P}$ imbalance problems, and maintaining farm profitability and reducing off-farm P losses. The IFSM accurately simulated the 2 farms based on farm data supplied by farm planners; these scenarios were used as the baseline conditions. The IFSM simulations of more accurate feeding of $\mathrm{P}$ (based on $\mathrm{P}$ required in animal diets) integrated with increased productivity of grassforage and increased proportion of forage in the diet reduced the $\mathrm{P}$ imbalance of 1 farm from 5.3 to $0.5 \mathrm{~kg} /$ ha and from 9.6 to $0.0 \mathrm{~kg} / \mathrm{ha}$ for the second farm. For both farms, soluble P lost to the environment was reduced by $18 \%$. Feed supplement purchases declined by $7.5 \mathrm{~kg} / \mathrm{cow}$ per year for dietary mineral $\mathrm{P}$, and by 1.04 and $1.29 \mathrm{t} /$ cow per year for protein concentrates through adoption of the PFM system. Moreover, when a land management practice of converting corn to grass was coupled with the precision feeding of $\mathrm{P}$ and improved forage management, IFSM predicted reductions of 5.8 and $9.3 \mathrm{~kg} / \mathrm{ha}$ of converted land sediment-bound $\mathrm{P}$ in erosion loss each year. The model predicted slight purchase increases in corn grain to offset reductions in corn

Received December 12, 2006.

Accepted April 14, 2007.

${ }^{1}$ Corresponding author: $\operatorname{ltg} 106 @ p s u . e d u$ silage production and feeding rates, but no appreciable change in the farm $\mathrm{P}$ balance due to land conversion. The model-based studies conducted on a farm-by-farm basis complement farm planning efforts in exploring innovative farming systems. Moreover, the results set a benchmark for potential benefits of PFM strategies, economically and environmentally.

Key words: forage management, phosphorus, precision feeding, simulation

\section{INTRODUCTION}

The Cannonsville Reservoir, part of the New York City drinking water supply system, routinely exhibits signs of eutrophication. Impairment of the reservoir threatens the quality of New York City's drinking water. Excess P from dairy-dominated agriculture within the contributing watershed (Cannonsville Reservoir Watershed; CRW) contributes approximately $70 \%$ of the annual nonpoint source total P load entering the Cannonsville Reservoir (Delaware County Watershed Affairs, 2002). The P-related impairment of the Cannonsville Reservoir is believed exacerbated by continuous soil $\mathrm{P}$ build-up resulting from the growing nutrient imbalances between farm $\mathrm{P}$ imports and exports (Wang et al., 1999). An increasing number of NY farm fields have tested high and very high in soil $\mathrm{P}$ over the past $20 \mathrm{yr}$, with currently almost $50 \%$ of agricultural fields testing high or very high in soil P (Ketterings et al., 2005).

Grassland in the northeastern United States is underutilized, which means that it is not managed intensely and is not producing high yields. Average grass yield for New York during 2002 to 2005 was 5.8 t of $\mathrm{DM} /$ ha (USDA, 2005), and grass yield for southeastern NY, including Delaware County, was $6 \mathrm{t}$ of DM/ha (Knoblauch et al., 2005). When forage production of a farm is low, more purchased feed supplement is required to satisfy animal feed needs. Northeastern farming operations often import feed grain and supplements from the Midwestern United States. This one-way transfer of nutrients increases northeastern $\mathrm{P}$ imbal- 
ances as $\mathrm{P}$ imports in purchased feed and fertilizers quickly exceed $P$ exports in milk, meat, or off-farm sales of harvested crops. Purchased animal feeds account for 65 to $85 \%$ of $\mathrm{P}$ imported annually (Cerosaletti et al., 1998). Other farm-scale studies within the CRW (Rotz et al., 2002; Cerosaletti et al., 2004) have shown that 42 to $63 \%$ of the imported $\mathrm{P}$ remains on the farms.

The NRC (2001) recommends that the typical dairy cow diet contains between 0.32 and $0.38 \% \mathrm{P}$, depending on milk production. Despite the NRC safety factor, many dairy herds are fed dietary $\mathrm{P}$ levels in excess of the published recommendations. In a survey conducted on dairy farms in New York, Pennsylvania, Delaware, Maryland, and Virginia, Dou et al. (2003) found dairy producers fed $0.44 \%$ dietary $\mathrm{P}$ (25\% above NRC recommendations). The common practice of overfeeding $\mathrm{P}$ to livestock, mainly to dairy cows, originates from the belief that high $\mathrm{P}$ diets improve animal reproductive performance. Still, intake of $\mathrm{P}$ by dairy cows had a significant impact on $\mathrm{P}$ excretion (Ebeling et al., 2002; Cerosaletti et al., 2004).

Currently, best management practices (BMP) are being implemented under the Watershed Agricultural Program (Walter and Walter, 1999; Delaware County Watershed Affairs, 2002) to address the P-related impairment of the Cannonsville Reservoir. These BMP, which are typically structural or management based, are designed to control off-field $\mathrm{P}$ transport to streams but do not address long-term on-farm $\mathrm{P}$ imbalances. Over time, the effectiveness of such BMP may be limited as soil $\mathrm{P}$ build-up continues. Hence, identifying and targeting the root cause of the $\mathrm{P}$ imbalance is critical to the long-term health and quality of the reservoir.

Personnel from Cornell University Cooperative Extension $(\mathbf{C C E})$ of Delaware County are investigating a farm-scale BMP that directly targets the root cause of $P$ build-up on farms. This BMP, precision feed management (PFM), addresses farm-level P imbalance by managing imported and on-farm $\mathrm{P}$ sources through $3 \mathrm{key}$ strategies. The first, involves recommendation-based $\mathrm{P}$ feed rations. The second improves production and use of on-farm forage. Together these 2 efforts reduce purchased feed $\mathrm{P}$ imports to a farm and $\mathrm{P}$ excreted in manure. Moreover, increasing productivity of homegrown forages promotes recycling and reuse of $P$ on the farm. The third strategy converts corn land to grass, which helps reduce erosion and associated nutrient losses from farm fields, particularly those previously in corn silage production.

Thus far, the potential for the Delaware County PFM farm program to address farm $\mathrm{P}$ imbalance appears to be significant. Cerosaletti et al. (2004) implemented precision diet formulation and delivery on 2 pilot CRW farms. They decreased feed $\mathrm{P}$ intake by $25 \%$ without negatively affecting milk production. Concurrently, manure $\mathrm{P}$ excretions decreased by $33 \%$, and the $\mathrm{P}$ imbalances (imports minus exports) decreased by $49 \%$. As part of the continuing Delaware County PFM program, implementation is occurring on more farms in the CRW. To complement these encouraging results and to successfully implement PFM efforts on more farms, a more comprehensive and predictive method is needed to plan and evaluate the farm PFM strategies. Such a method could help quantify the impacts of PFM efforts on milk production, farm profitability, and farm-level nutrient flows, as well as assess farm system options. Currently, there are virtually no on-farm data available with which to compare various PFM strategies beyond the 2 CRW pilot farms. Thus, the most feasible method of analysis is through use of a whole-farm model.

Consequently, the purpose of this study was to evaluate and quantify the economic and P-related environmental impacts of PFM strategies for a farm-scale enterprise. This study applied the integrated farm system model (IFSM; Rotz and Coiner, 2006) to the 2 pilot CRW farms. Using this modeling system, several PFM farm planning strategies were evaluated and quantified with regard to their relative impacts on $\mathrm{P}$ balance, offfarm P loss, and farm profitability.

\section{MATERIALS AND METHODS}

\section{Study Area and Farm Descriptions}

The 2 study farms are in the upper half of the CRW (Figure 1). The CRW $\left(917 \mathrm{~km}^{2}\right)$, located in Delaware County, NY, is one of the largest source watersheds for the New York City drinking water supply. Elevation in the watershed ranges from 333 to $1,018 \mathrm{~m}$ above mean sea level. Climate is characterized as humid continental with an average annual temperature of about $8^{\circ} \mathrm{C}$ and precipitation of approximately $1,070 \mathrm{~mm} / \mathrm{yr}$ ( 20 -yr average). Major land uses are forest (70\%), agriculture $(26 \%)$, water bodies $(3 \%)$, and developed land (1\%; Lounsbury, 2001). Agricultural activities consist primarily of dairy farming, and agricultural land uses are typically pasture, corn, and hay crops that are grown to support dairy farming.

The 2002 Census of Agriculture data indicated that the dairy farms in Delaware County average 67 cows with average and median farm sizes of 98 and 80 ha, respectively (USDA, 2002). The 2 CRW dairy farms used, identified as R-farm and $\mathrm{W}$-farm, were close to the county average in size. These farms were selected for detailed analysis because of data availability for modeling and their general similarity to other farms within the CRW. 


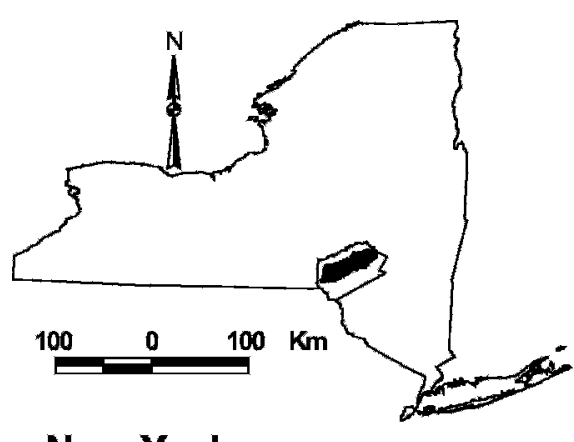

\section{General location of farms}

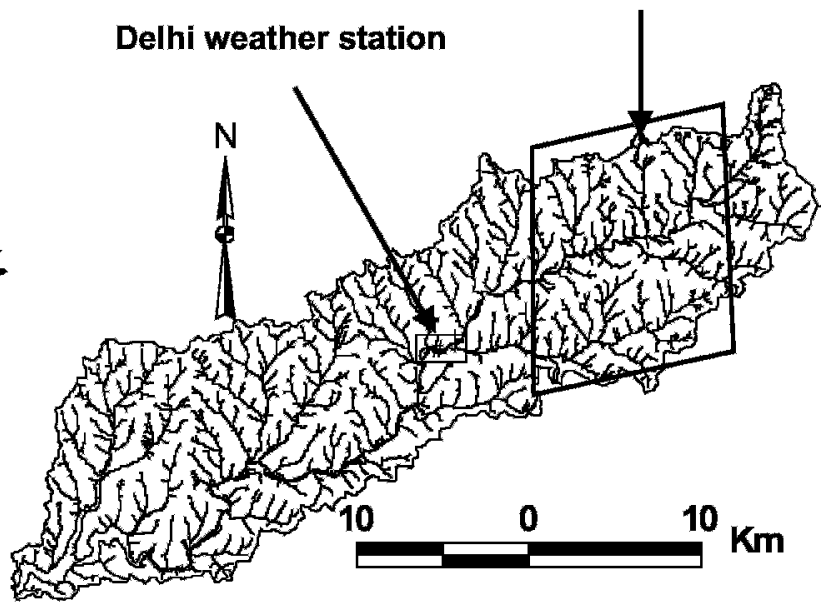

Cannonsville Reservoir Watershed

Figure 1. Location of study farms and a weather station in the Cannonsville Reservoir Watershed, New York.

\section{Farm Data}

Farm data were obtained from data gathered or calculated by the CCE planners of Delaware County. Farm data collection included farm characteristics, financial records, forage analysis, concentrate (grain/protein) formulas, dairy production records, and farm crop yield records. Silage yields were calculated from storage based on silo capacity charts. Nutrient balance data were estimated from imported and exported nutrient values using the procedure of Klausner et al. (1997).

$\boldsymbol{R}$-farm. The R-farm consisted of 120 ha of crop area on predominantly shallow loamy soils. Over the period of simulation, crops grown include corn for silage (12 ha), alfalfa (9 ha), grass hay (63 ha), and grass pasture (36 ha). The farm maintained Holstein dairy cows with 102 mature lactating cows (683 kg of BW), 40 heifers over $1 \mathrm{yr}$ old (517 $\mathrm{kg}$ of BW), and 37 heifers $<1 \mathrm{yr}$ in age (217 kg of BW). Cows were housed in a tie-stall barn; heifers were housed in tie-stall and free-stall barns. Milk yield of the farm was $8,966 \mathrm{~kg} / \mathrm{cow}$ per year. From May through October, lactating cows were fed a diet of dry grass hay, corn silage, and grazed forage (mostly grass) supplemented with a corn meal and soy hulls mix and a protein and mineral mix. From November through April, cows were fed a winter diet containing dry grass hay, corn silage, and grass silage supplemented with corn meal, soy hulls, and a protein and mineral mix. Average manure production of the farm was $275 \mathrm{t} / \mathrm{yr}$ on DM basis (9\% of the total manure produced) and contained $4.26 \% \mathrm{~N}, 1.64 \%$ phosphate $\left(\mathrm{P}_{2} \mathrm{O}_{5}\right)$, and $4.87 \%$ potash $\left(\mathrm{K}_{2} \mathrm{O}\right)$. Grass received $78 \%$ of the manure produced on the farm, with the remaining ma- nure applied to corn land. In addition, $\mathrm{N}$-fertilizer was applied to grass at a rate of $100 \mathrm{~kg}$ of N/ha. Fertilizers applied to corn included 34,17 , and $17 \mathrm{~kg} / \mathrm{ha}$ of $\mathrm{N}, \mathrm{P}_{2} \mathrm{O}_{5}$, and $\mathrm{K}_{2} \mathrm{O}$, respectively. Pastures received no fertilizer.

W-farm. The W-farm contained about 95 ha of cultivated crop area on predominantly shallow loamy soils. Crops grown on the farm included corn for silage (8 ha), alfalfa (16 ha), grass hay (42 ha), and grass pasture (28 ha). The farm had Holstein dairy cows with 52 mature lactating cows ( $637 \mathrm{~kg}$ of BW), 22 heifers $>1 \mathrm{yr}$ in age (470 kg of BW), and 27 heifers $<1 \mathrm{yr}$ in age (198 $\mathrm{kg}$ of BW). Cows were housed in a tie-stall barn and heifers in tie-stall and bedded-pack barns. Milk yield was $6,413 \mathrm{~kg} / \mathrm{cow}$ per year. From May through October, lactating cows were fed a diet of dry grass hay, corn silage, and grazed forage (mostly grass) supplemented with corn meal and citrus pulp mix and a protein and mineral mix. From November to April, cows were fed a winter diet containing dry grass hay, corn silage, and grass silage supplemented with corn meal and a protein and mineral mix. Average manure production of the farm was $139 \mathrm{t} / \mathrm{yr}$ on DM basis (9\% of the total manure produced) with $4.19 \% \mathrm{~N}, 1.56 \% \mathrm{P}_{2} \mathrm{O}_{5}$, and $5.10 \% \mathrm{~K}_{2} \mathrm{O}$. Grass fields received $60 \%$ of the manure produced on the farm, whereas $20 \%$ was applied to corn and the remaining $20 \%$ to the alfalfa. Additionally, $\mathrm{N}$-fertilizer was applied to grass at an average rate of $50 \mathrm{~kg}$ of N/ ha. Fertilizer applied to corn included 40, 17, and 17 $\mathrm{kg} / \mathrm{ha}$ of $\mathrm{N}, \mathrm{P}_{2} \mathrm{O}_{5}$, and $\mathrm{K}_{2} \mathrm{O}$, respectively. Pastures received no fertilizer.

\section{Model Description}

The IFSM (formerly the Dairy Forage System model; Rotz and Coiner, 2006) is a comprehensive farm-scale 
model that simulates long-term environmental impact and farm profitability for various technologies and management strategies applied to a farm system. The Dairy Forage System model was used in studying farm planning strategies mainly in the northeastern and central United States and Canada (Andresen et al., 2001; Soder and Rotz, 2001). The IFSM was chosen because it reports relative environmental and economic benefits of various management strategies at the farm scale and was successfully used to evaluate economic and environmental statuses of farming systems in the northeastern United States (Rotz et al., 2002). The IFSM model is composed of different components that help estimate farm performance, profitability, and potential nutrient accumulation and loss to the environment. The following are summaries of model components pertinent to this study; a complete description of IFSM can be found in Rotz and Coiner (2006).

The model evaluates the performance of a farm enterprise by predicting crop yield and quality; on-farm feed, milk, and manure produced; feeds sold, supplemental feeds purchased, or both; and resources expended, such as labor, fuel, and equipment used. Feed allocation in IFSM is based on the nutritive values of available feeds and the nutrient requirements of different groups of animals composing the dairy herd. A linear ration optimization program is used to obtain maximum herd milk production with minimum cost rations (Rotz and Coiner, 2006). To satisfy animal needs and maintain milk production, the model purchases supplemental feeds when insufficient feed is produced on the farm. The model user sets a target milk production that is maintained when the nutritive value of available feeds is sufficient to meet nutrient requirements.

The model allocates various amounts of forage for a diet based on different animal groups (early-, mid-, and late-lactating; dry cows; heifers) and the forage required for the diet. When adjusting the forage level of dairy cow diets, IFSM provides forage options for forage feeding: high-forage diet and low-forage diet (Rotz et al., 1999). For high-forage diet, a maximum amount of forage is fed, while meeting the energy and protein requirements with supplemental feeds. For the lowforage diet option, a minimum amount of forage is included in ration, while meeting a specified minimum roughage requirement for maintaining good rumen function.

The economic component of IFSM uses a simple, but comprehensive accounting that uses production costs and incomes to compute net-return of a farm enterprise. Production costs include crop production, harvest, storage, feeding, and other production-related activities. Farm income includes receipts from sales of milk, animals, and crops.
The $\mathrm{P}$ component of IFSM predicts $\mathrm{P}$ balances on the farm, as well as off-farm runoff, leaching, erosion, and related $\mathrm{P}$ losses. The model calculates the farm $\mathrm{P}$ balance as the quantity of $\mathrm{P}$ imported in feed and fertilizer minus the quantity exported in milk, animals, manure, and crops. The quantity and characteristics of $\mathrm{P}$ produced in the manure are calculated as functions of the quantity and $\mathrm{P}$ content of feed consumed. To predict $\mathrm{P}$ loss from agricultural fields on a farm, the model uses equations based on those used in the erosion productivity impact calculator (Jones et al., 1984) and the soil and water assessment tool (SWAT; Neitsch et al., 2002). The IFSM prediction methods for off-farm P loss are described in detail by Sedorovich et al. (2005).

In addition to $\mathrm{P}$, IFSM predicts $\mathrm{N}$ imports and exports for a farm and determines potential losses in volatilization, denitrification, and leaching (Rotz and Coiner, 2006). In IFSM, a basic hydrology approach is used, with particular fields in a farm lumped together and all crop fields generalized by a single soil and slope representation. Thus, there is no spatial representation of fields within a farm.

\section{Weather Data}

For the 2 study farms, IFSM simulation results represent average annual predictions using $25 \mathrm{yr}$ of historical weather data collected from the National Climate Data Center database. The weather data required by IFSM include daily values of total precipitation, maximum and minimum temperatures, and solar radiation. For the $\mathrm{R}$-farm and $\mathrm{W}$-farm, precipitation and temperature data from the NY Delhi station were used (1978 to 2002). Delhi is located in the center of the CRW (Figure 1). Solar radiation data, not available from the Delhi station, were acquired from the Cooperstown station located approximately $45 \mathrm{~km}$ north of Delhi.

\section{Scenario Descriptions and Modeling}

Baseline and selected alternative farm planning scenarios were modeled for each farm (Table 1). The baseline scenarios represent the study farms' current production systems, without PFM strategies in place. The alternative farm planning scenarios involve various combinations of the ongoing PFM strategies and were developed with help from personnel from CCE of Delaware County, NY. The CCE personnel designed the PFM efforts as farm-scale BMP that would directly target the root cause of $\mathrm{P}$ build-up on the farm, ultimately reducing $\mathrm{P}$ loadings to the Cannonsville Reservoir. Because maintaining economic viability of the farms is an important part of the Delaware County PFM program, the potential for economic benefits from implementing 
Table 1. Description of baseline and precision feed management (PFM)-based scenarios modeled in the integrated farm system model (IFSM)

\begin{tabular}{ll}
\hline Scenario & \multicolumn{1}{c}{ Description } \\
\hline Baseline & Current farming system; conditions before management changes \\
Scenario 1 & Precision diet formulation and delivery \\
Scenario 2 & Scenario 1 + increased grass productivity and a high-forage diet \\
Scenario 3 & Scenario 2 $+50 \%$ corn land converted to grass \\
Scenario 4 & Scenario $2+100 \%$ corn land converted to grass \\
\hline
\end{tabular}

these scenarios was considered. Also, because $\mathrm{N}$ was necessarily imported and exported from the farm in fertilizer and manure, its environmental impacts were evaluated. The soil P levels for both farms are in the medium to high range, precluding a yield reduction from reduced $\mathrm{P}$ levels in manure. Thus, the alternative planning strategies include precision diet formulation and delivery, on-farm forage management and utilization, and land use management (Table 2). For all scenarios, the level of milk production, amount of grazed forage, and alfalfa hay and silage production were held at baseline levels.

Baseline Scenario. The baseline scenarios represented the current economic and environmental conditions of each dairy farm as estimated from data gathered by the CCE planners. Consequently, significant efforts were made to ensure that the baseline scenarios modeled in IFSM reflect current conditions for the farms.
Scenario 1. This scenario involved application of precision diet formulation and delivery only, with an emphasis on feeding $\mathrm{P}$ at a prescribed rate. The precision diet formulation and delivery component of PFM involves modifying animal diets to minimize overfeeding of nutrients and manure nutrient excretions. Dietary nutrient levels for dairy cattle were reduced $22 \%$ from the $\mathrm{P}$ levels fed under the baseline scenario to the NRC recommended $P$ levels (NRC, 2001), as shown in Table 2. Reductions in dietary $\mathrm{P}$ rates were substantial for the lactating cows: from 0.50 to $0.38 \%$ on the Rfarm and from 0.48 to $0.37 \%$ for the $\mathrm{W}$-farm. Precision diet formulation and delivery, especially with regard to $\mathrm{P}$, was identified as a critical component of the PFM strategy in reducing $\mathrm{P}$ loading to the CRW (Delaware County Watershed Affairs, 2002). Therefore, it was imperative that this approach be considered in all farm planning scenarios simulated.

Table 2. Summary of precision feed management (PFM) strategies and assumptions implemented for each farm under each modeled scenarios

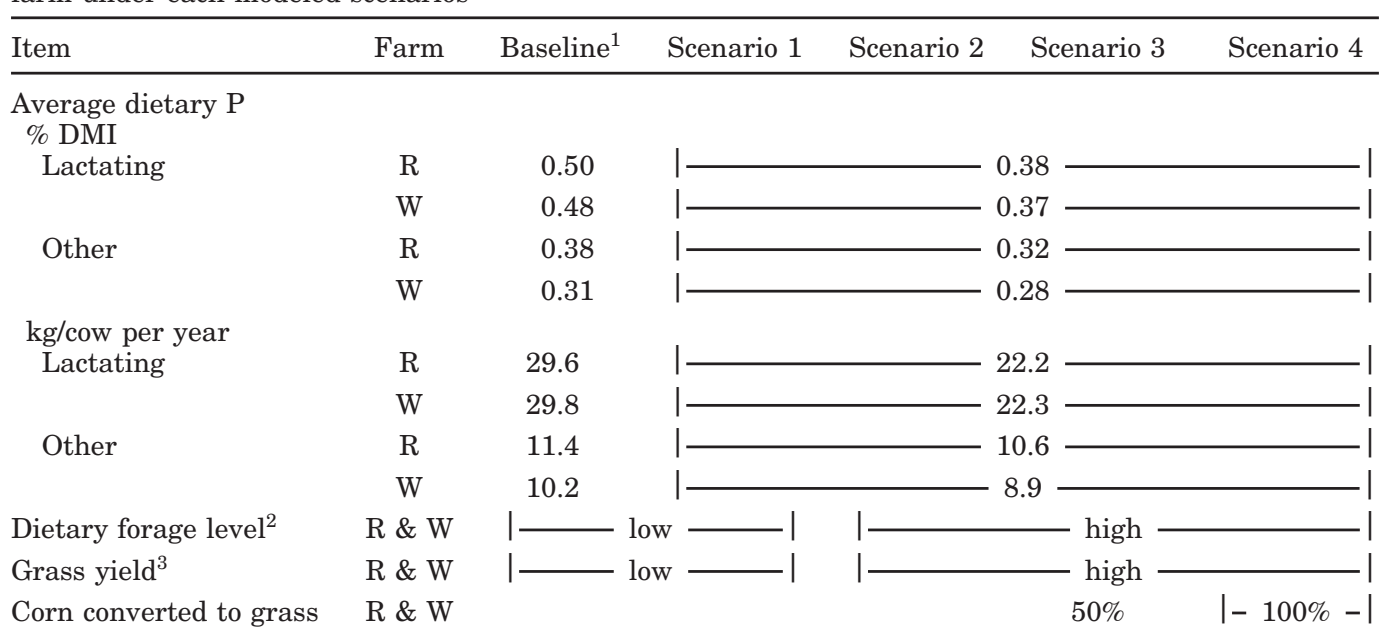

\footnotetext{
${ }^{1}$ Baseline $=$ current farming system; scenario $1=$ precision diet formulation and delivery; scenario $2=$ scenario $1+$ increased grass productivity and a high-forage diet; scenario $3=$ scenario $2+50 \%$ corn land converted to grass; scenario $4=$ scenario $2+100 \%$ corn land converted to grass;

${ }^{2}$ Low-forage diet = lowest forage composition possible without compromising proper rumen function; highforage diet $=$ highest forage composition possible while providing sufficient energy for maintenance and production.

${ }^{3}$ Low-yield was 6.0 and $5.1 \mathrm{t}$ of DM/ha for R- and W-farms, respectively; high-yield was $8.0 \mathrm{t}$ of DM/ha for both farms.
} 
Scenario 2. Scenario 2 added 2 practices of on-farm forage management and utilization to the conditions used for scenario 1: A) increasing productivity of grass fields, and B) feeding cows with a high-forage diet. The on-farm forage management and utilization component of PFM involves increasing productivity of on-farm produced forages and their utilization in the animal diet. That is, production and harvesting strategies are intensively managed to increase yield and quality of grass forage. Feeding these high quality forages decreases the need for feed $\mathrm{P}$ imports. This strategy has an extra benefit of increasing reuse of soil $\mathrm{P}$ on the farm through the increased productivity of homegrown forages.

The yield goal for high-intensity grass production was set to $8 \mathrm{t}$ of $\mathrm{DM} / \mathrm{ha}$ as per the suggestion of CCE planners. To increase the yield and quality of grass production for both farms, rates of $\mathrm{N}$ fertilizer were increased by $100 \mathrm{~kg} / \mathrm{ha}$ for the R-farm and $130 \mathrm{~kg} / \mathrm{ha}$ for the Wfarm from the baseline scenario, and hay harvest for the $\mathrm{W}$-farm was increased from 2 cuttings in the baseline to 3 cuttings. For the R-farm, the number of cutting for hay harvest was kept to 3 cutting as in the baseline. The necessary increases in $\mathrm{N}$ application rate and hay cuttings were found by performing iterative IFSM runs with different application rates of $\mathrm{N}$ fertilizer and harvesting times to achieve the prescribed yield goal. Predicted grass forage yield response to $\mathrm{N}$ fertilizer was $20 \mathrm{~kg}$ of DM/ $\mathrm{kg}$ of $\mathrm{N}$ and $30 \mathrm{~kg}$ of $\mathrm{DM} / \mathrm{kg}$ of $\mathrm{N}$ for the $\mathrm{R}$-farm and W-farm, respectively. A field trail study by Cherney et al. (2003) in New York farms using $\mathrm{N}$ fertilizer applications of $0,112,224 \mathrm{~kg}$ of $\mathrm{N} / \mathrm{h}$ a resulted in grass yields of $3,074,7,388$, and $9,621 \mathrm{~kg}$ of $\mathrm{DM} / \mathrm{ha}$, respectively. Yield responses to $\mathrm{N}$ fertilizer for the field trial study were 39 and $20 \mathrm{~kg}$ of DM/kg of N. Predicted grass yield responses to $\mathrm{N}$ fertilizer for the $\mathrm{R}$-farm and $\mathrm{W}$-farm were comparable with the field study. To represent a high-forage diet in IFSM by increasing forage utilization, the high-forage feed option in the model was selected. A model parameter that represents total feed consumption by cows was adjusted to keep the total DMI the same as that of the baseline scenario.

Scenario 3 and Scenario 4. Scenarios 3 and 4 retained the practices used in scenario 2 and added the land use management strategy of converting corn production areas to grass production. Corn silage land use in the CRW was identified as high risk for erosion and associated $\mathrm{P}$ loss. A modeling study of the CRW by Tolson and Shoemaker (2004) reported that 58\% of the watershed $\mathrm{P}$ loss comes from corn production land that, in turn, represents only $1.2 \%$ of the total watershed. Hence, studying effects of this strategy on reducing off-farm sediment and P losses and purchased grain imports was of interest.
In scenario 3 , half of the corn area was converted to grass production, and half of the manure that was previously applied to corn was applied to grass. In Scenario 4, the entire corn area was converted to grass, and all manure that had been allocated to corn fields before conversion was applied to the grass fields. These scenarios were suggested by the CCE planners to determine the effects that those scenarios would have on purchased grain imports and reducing off-farm sediment and sediment-bound P losses.

\section{RESULTS AND DISCUSSION}

\section{Baseline Simulations and Verifications}

Predicted average crop yields and nutritive contents matched with crop yield data collected from farm records (Table 3). For example, predicted corn silage yield for R-farm, $15.7 \mathrm{t}$ of DM/ha, closely matched that farm's average observed yield of $15.8 \mathrm{t}$ of DM/ha. Similarly, the predicted corn silage yield of $9.1 \mathrm{t}$ of $\mathrm{DM} / \mathrm{ha}$ closely matched the average observed yield of $8.9 \mathrm{t}$ of $\mathrm{DM} / \mathrm{ha}$ for the W-farm, which historically exhibited reduced yields due to lower soil productivity and less intensive management than the R-farm.

The IFSM predictions of feed use, production, and purchases for the 2 farms were compared with the actual farm metrics (Table 4). Based on the farm data records, an average of $40 \mathrm{t}$ of DM of forage was sold annually from the R-farm under baseline conditions, whereas the $\mathrm{W}$-farm rarely sold forage. The long-term predicted forages sold of $41 \mathrm{t}$ from the R-farm and 0.0 $\mathrm{t}$ from the $\mathrm{W}$-farm were, therefore, comparable with actual values.

The IFSM-predicted, long-term $\mathrm{P}$ balances ( $\mathrm{P}$ imported - $\mathrm{P}$ exported) for the 2 farms were compared with $\mathrm{P}$ balances calculated from measured data via a nutrient mass balance approach (Klausner et al., 1997). Similar to IFSM, the procedure calculated farm mass $\mathrm{P}$ balances by subtracting farm nutrient $\mathrm{P}$ exports (milk, animals, and crops) from nutrient $P$ exports (in feed supplements, crops, and fertilizer). Though, in general, predicted and actual feed imports and exported compared well, IFSM-predicted P import value shown in Table 4, especially for the W-farm, was slightly higher than the P import value estimated using the Klausner et al. (1997). This discrepancy was likely because the $\mathrm{P}$ imported predicted by the IFSM takes into account the amount of $\mathrm{P}$ with the purchased salts and minerals. Nevertheless, such consideration was not made in the $P$ imports calculated by the Klausner et al. (1997) method because there were no actual data on purchased salts and minerals (Table 4).

Overall, IFSM-predicted, long-term $\mathrm{P}$ balances for the 2 farms compared well with farm $\mathrm{P}$ balances calcu- 
Table 3. Comparison of actual farm data and integrated farm system model (IFSM)-predicted average crop yields and nutritive contents

\begin{tabular}{|c|c|c|c|c|c|c|}
\hline \multirow[b]{2}{*}{ Crop } & \multicolumn{2}{|c|}{ Yearly yield, $\mathrm{t}$ of $\mathrm{DM} / \mathrm{ha}$} & \multicolumn{2}{|c|}{$\mathrm{CP}, \%$ of $\mathrm{DM}$} & \multicolumn{2}{|c|}{$\mathrm{NDF}, \%$ of $\mathrm{DM}$} \\
\hline & Actual $^{1}$ & Predicted $^{2}$ & Actual & Predicted & Actual & Predicted \\
\hline \multicolumn{7}{|l|}{$\mathrm{R}$-farm } \\
\hline Alfalfa, 9 ha (3 cuttings) & 6.8 & 6.8 & 22.0 & 22.0 & 42.0 & 42.1 \\
\hline Grass, 99 ha ( 3 cuttings $)$ & 6.0 & 6.0 & 18.0 & 18.1 & 51.0 & 50.0 \\
\hline Corn, 12 ha (silage) & 15.8 & 15.7 & 9.0 & 9.2 & 46.0 & 46.5 \\
\hline \multicolumn{7}{|l|}{ W-farm } \\
\hline Alfalfa, 16 ha (3 cuttings) & 5.0 & 5.0 & 22.0 & 21.2 & 40.0 & 40.2 \\
\hline Grass, 40 ha ( 2 cuttings $)$ & 5.0 & 5.1 & 18.0 & 18.2 & 51.0 & 50.6 \\
\hline Corn, 8 ha (silage) & 8.9 & 9.1 & 9.0 & 9.2 & 45.0 & 45.3 \\
\hline
\end{tabular}

${ }^{1}$ Actual average farm data based on 2001 to $2003 \mathrm{R}$-farm records and $2003 \mathrm{~W}$-farm records.

${ }^{2}$ IFSM-predicted values are average annual using a 25-yr farm analysis.

lated from measured data via a nutrient mass balance approach by Klausner et al. (1997). The IFSM-predicted $\mathrm{P}$ balance was $0.1 \mathrm{~kg} / \mathrm{ha}$ greater than the nutrient mass balance for the R-farm and $0.8 \mathrm{~kg} / \mathrm{ha}$ for the $\mathrm{W}$-farm (Table 4).

Due to limited availability of observed data, IFSMpredicted off-farm $\mathrm{P}$ losses could be verified only for the $\mathrm{R}$-farm. The IFSM-simulated long-term average P loss rates from the R-farm were 0.53 and $2.3 \mathrm{~kg} / \mathrm{ha}$ for soluble $\mathrm{P}$ and total $\mathrm{P}$, respectively. The IFSM-simulated $\mathrm{P}$ loss rates were compared with average $\mathrm{P}$ loss rates of similar fields generated by SWAT as representative of the R-farm watershed from 1993 to 1995 (Gitau and
Gburek, 2005). The SWAT-generated average P loss rates were 0.73 and $1.9 \mathrm{~kg} / \mathrm{ha}$ for soluble $\mathrm{P}$ and total $\mathrm{P}$, respectively. Thus, the IFSM-simulated soluble $\mathrm{P}$, sediment-bound $\mathrm{P}$, and total $\mathrm{P}$ loss rates compared well with the field-level SWAT predictions.

Simulated baseline scenario net returns for the 2 study farms represent long-term average annual values estimated under typical prices and costs of production. Predicted costs and returns for the farms were compared with the farm's financial data and deemed representative of farms of this size and type in this region. The purpose of this modeling study was to determine the relative change in farm net-return resulting from

Table 4. Comparison of actual farm data and integrated farm system model (IFSM)-predicted annual feed production, purchases, and nutrient mass balances

\begin{tabular}{|c|c|c|c|c|}
\hline \multirow[b]{2}{*}{ Item } & \multicolumn{2}{|c|}{$\mathrm{R}$-farm } & \multicolumn{2}{|c|}{ W-farm } \\
\hline & Actual $^{1}$ & Predicted $^{2}$ & Actual $^{1}$ & Predicted $^{2}$ \\
\hline Total hay and silage, $\mathrm{t}$ of $\mathrm{DM}$ & 312 & 337 & 157 & 172 \\
\hline Corn silage, $\mathrm{t}$ of $\mathrm{DM}$ & 165 & 161 & 60 & 64 \\
\hline Grazed grass forage, $\mathrm{t}$ of $\mathrm{DM}$ & 182 & 182 & 74 & 74 \\
\hline Forage sold, $t$ of DM & 40 & 41 & 0 & 0 \\
\hline Purchased corn grain, $t$ & 164 & 199 & 33 & 40 \\
\hline Purchased protein supplement, t & 128 & 139 & 81 & 81 \\
\hline \multirow[t]{2}{*}{ Purchased salts and mineral, $t$} & $\mathrm{NA}^{4}$ & 9.2 & $\mathrm{NA}^{4}$ & 3.5 \\
\hline & Estimated $^{3}$ & Predicted $^{2}$ & Estimated $^{3}$ & Predicted $^{2}$ \\
\hline $\mathrm{P}$ imported, $\mathrm{kg} / \mathrm{ha}$ & 18.7 & 19.6 & 7.6 & 9.9 \\
\hline Feed & 16.9 & 18.4 & 6.5 & 9.3 \\
\hline Fertilizer & 1.5 & 0.7 & 1.1 & 0.6 \\
\hline Animal & 0.3 & - & - & - \\
\hline Precipitation & - & 0.5 & - & 0.5 \\
\hline $\mathrm{P}$ exported & 9.2 & 10 & 3.2 & 4.6 \\
\hline Milk and animal & 8.3 & 8.9 & 3.2 & 4.6 \\
\hline Feed & 0.9 & 1.1 & - & - \\
\hline P balance (imported - exported) & 9.5 & 9.6 & 4.4 & 5.2 \\
\hline $\mathrm{N}$ imported & 144 & 155 & 114 & 136 \\
\hline $\mathrm{N}$ exported & 53 & 59 & 30 & 27 \\
\hline
\end{tabular}

${ }^{1}$ Actual average farm data based on 2001 to $2003 \mathrm{R}$-farm records and $2003 \mathrm{~W}$-farm records.

${ }^{2}$ IFSM-predicted values are average annual using a 25 -yr farm analysis.

${ }^{3}$ Nutrient balance estimated using Klausner et al. (1997) approach.

${ }^{4}$ Actual data were not available. 
implementing different management scenarios; actual farm costs and profits are not presented to maintain confidentiality.

\section{Impacts of Alternative Farm System Scenarios}

Table 5 shows simulation results related to crop yield, nutritive contents, and feed use for all scenarios applied to the 2 study farms. Table 6 presents the average daily diet composition of lactating cows for a simulation year selected at random for demonstration purposes. Because no grazing occurred from November to March, average daily diet composition results are presented for winter (November to March) and nonwinter (April to October) seasons. Table 6 also presents forage levels of cow diet and total DMI of lactating cows under all scenarios simulated.

Tables 7 and 8 present predicted P- and N-related environmental characteristics and economic variables related to costs of production and farm incomes for all scenarios simulated. Tables 7 and 8 provide values predicted for the baseline scenario and changes from the baseline values for each alternative scenario for the $R$ farm and the W-farm, respectively. The changes were calculated as the difference in value between the alternative and baseline scenarios such that a negative change represented a reduction and a positive change represented an increase in the predicted value compared with the baseline condition. Thus, the direction and magnitude of change in economic or environmental factors resulting from implementation of an alternative scenario are shown. Percentage changes from the baseline for erosion, $\mathrm{P}$ losses, $\mathrm{P}$ balance, $\mathrm{N}$ leaching, and income for each alternative scenario are shown in Figure 2.

Feed Production. Reducing the dietary $\mathrm{P}$ rations to NRC (2001) recommendations, via scenario 1, decreased the amount of vitamins and mineral $P$ supplements purchased by 3.7 and $1.1 \mathrm{t} / \mathrm{yr}$ for the $\mathrm{R}$-farm and the W-farm, respectively (Table 5). Accounting for differences in farm size, the reduction for both farms was equivalent to $7.5 \mathrm{~kg} / \mathrm{cow}$ per year of dietary P level, a $25 \%$ reduction compared with the baseline scenario (calculated from Table 2).

Scenario 2 increased the amount of homegrown forage and decreased the amount of imported feed protein supplements. In consultation with CCE planners, production of grass silage as the primary harvest and storage method was increased from $198 \mathrm{t}$ of DM in the baseline scenario to $331 \mathrm{t}$ of DM for scenario 2 for the $\mathrm{R}$-farm, and from 101 to $155 \mathrm{t}$ of DM for the W-farm (Table 5). Increasing the forage productivity and the proportion of forage in the diet reduced the need for purchased feed, mainly the protein supplements. As a result, the annual imported feed as protein concentrate purchased declined by $106 \mathrm{t}$ for the R-farm and $67 \mathrm{t}$ for the W-farm (Table 5). An undesired but minor impact of scenario 2 for the $\mathrm{R}$-farm was a $0.7 \%$ predicted reduction of CP in the corn silage. This reduction was likely due a simulated delay in corn silage harvest by $2 \mathrm{~d}$ due to the increased demand for labor and machinery in forage production.

Scenarios 3 and 4 altered the amount of forage produced on the farms by converting corn land to grass. Thus, the required area of high-yield grass for each farm increased compared with scenario 2. Also, IFSM predicted that more supplemental concentrates, mainly corn grain, must be purchased to offset the reduction in available feed energy through reduced corn silage production. In scenario 3 for example, the R-farm needed 67 ha of high-yield grass (8.1 t of DM/ha) to produce the amount of forage required to feed the cows with high-forage diets and still produce the equivalent amount of forage for off-farm sale (41 t of DM) as in scenario 2. Under scenario 4, with all corn fields converted to grass, 72 ha of high-yield grass ( $8 \mathrm{t}$ of $\mathrm{DM} / \mathrm{ha}$ ) were required. This was equivalent to $97 \%$ utilization of the entire grass area (63 ha) plus the 12 ha of corn converted to grassland. Moreover, with regard to feed, the $\mathrm{R}$-farm needed to purchase 18 and $23 \mathrm{t}$ more supplemental grain, under scenario 3 and scenario 4, respectively, as compared with scenario 2 (Table 5).

Under scenario 3 for the W-farm, 24 ha of high-yield grass ( $8 \mathrm{t}$ of DM/ha) was required to produce the amount of forage needed to support the high-forage diets. This assumed that, as in the baseline scenario, no extra forage was produced for sale. Scenario 4 converted all corn fields to grass, increasing the area of grass from 42 ha in scenario 3 to 46 ha. In this scenario only 32 ha of the 46 ha of grass were required to provide the requisite amount of forage. Under scenarios 3 and 4, respectively, IFSM predicted that the W-farm needed to purchase 8 and $11 \mathrm{t}$ of DM corn grain supplement to offset the reduction in feed energy available in corn silage, compared with scenario 2 conditions (Table 5).

Feed Utilization. Average diet composition for baseline and alternative scenarios are presented in Table 6 for a typical simulation year. Baseline diets, which represent actual diets fed in the $\mathrm{R}$-farm and the $\mathrm{W}$-farm before implementation of precision diet formulation and improved forage management, averaged 48 and $62 \%$ of the diet DM as forage for the R-farm and W-farm, respectively (Table 6). Dietary forage levels after implementation of improved forage management averaged 66 and $86 \%$ of total ration DM for the R-farm and Wfarm, respectively, across winter and nonwinter feeding periods. Both farms saw similar increases in percent forage in total ration DM with the R-farm increasing 
Table 5. Integrated farm system model (IFSM)-predicted average annual crop yields, nutritive contents, and feed production and utilization (considering a 25-yr farm analysis) for all scenarios simulated for the R- and W-farms

\begin{tabular}{|c|c|c|c|c|c|c|c|c|c|c|}
\hline \multirow[b]{2}{*}{ Item } & \multicolumn{5}{|c|}{$\mathrm{R}$-farm (102 mature cows) } & \multicolumn{5}{|c|}{$\mathrm{W}$-farm (52 mature cows) } \\
\hline & Baseline $^{1}$ & Scenario 1 & Scenario 2 & Scenario 3 & Scenario 4 & Baseline $^{1}$ & Scenario 1 & Scenario 2 & Scenario 3 & Scenario 4 \\
\hline Alfalfa, ha & 9 & 9 & 9 & 9 & 9 & 16 & 16 & 16 & 16 & 16 \\
\hline Yield, t of DM/ha & 6.8 & 6.8 & 6.8 & 6.8 & 6.8 & 5.1 & 5.1 & 5.1 & 5.1 & 5.1 \\
\hline $\mathrm{CP}, \% \mathrm{DM}$ & 22 & 22 & 22 & 22 & 22 & 21.2 & 21.2 & 21.2 & 21.2 & 21.2 \\
\hline $\mathrm{NDF}, \% \mathrm{DM}$ & 42.1 & 42.1 & 42.1 & 42.1 & 42.1 & 40.2 & 40.2 & 40.2 & 40.2 & 40.2 \\
\hline Grass, ha & 63 & 63 & 63 & 69 & 75 & 42 & 42 & 42 & 46 & 50 \\
\hline Harvested grass, ha & 47 & 47 & 61 & 67 & 72 & 22 & 22 & 24 & 28 & 32 \\
\hline Pasture, ha & 36 & 36 & 36 & 36 & 36 & 28 & 28 & 28 & 28 & 28 \\
\hline Yield, ${ }^{2} \mathrm{t}$ of $\mathrm{DM} / \mathrm{ha}$ & 6.0 & 6.0 & 8.0 & 8.1 & 8.0 & 5.1 & 5.1 & 8.0 & 8.0 & 8.0 \\
\hline Yield, $t$ of DM & 182 & 182 & 180 & 180 & 182 & 74 & 74 & 74 & 74 & 73 \\
\hline $\mathrm{CP}, \% \mathrm{DM}$ & 18.1 & 18.1 & 19.3 & 19.3 & 19.5 & 18.2 & 18.2 & 19.0 & 19.1 & 19.4 \\
\hline $\mathrm{NDF}, \% \mathrm{DM}$ & 50 & 50 & 49 & 49 & 48.4 & 50.6 & 50.6 & 49.2 & 49.3 & 49.3 \\
\hline Grass/alfalfa silage produced, $\mathrm{t}$ of DM & 198 & 198 & 331 & 401 & 448 & 101 & 101 & 155 & 177 & 195 \\
\hline Grass/alfalfa hay produced, $t$ of DM & 114 & 114 & 115 & 121 & 133 & 71 & 71 & 87 & 92 & 102 \\
\hline Forage sold, $\mathrm{t}$ of DM & 41 & 41 & 39 & 41 & 40 & 0 & 0 & 0 & 0 & 0 \\
\hline Corn silage, ha & 12 & 12 & 12 & 6 & 0 & 8 & 8 & 8 & 4 & 0 \\
\hline Yield, $\mathrm{t}$ of $\mathrm{DM} / \mathrm{ha}$ & 15.7 & 15.7 & 15.7 & 15.5 & & 9.1 & 9.1 & 9.1 & 9.1 & \\
\hline Yield, t of DM & 161 & 161 & 162 & 73 & 0 & 63 & 63 & 63 & 30 & 0 \\
\hline $\mathrm{CP}, \% \mathrm{DM}$ & 9.4 & 9.4 & 8.7 & 9.2 & & 9.2 & 9.2 & 9.2 & 9.3 & \\
\hline $\mathrm{NDF}, \% \mathrm{DM}$ & 46.5 & 46.5 & 46.4 & 47.6 & & 45.3 & 45.3 & 45.3 & 46.2 & \\
\hline Purchased protein supplement, $t$ of DM & 139 & 139 & 33 & 29 & 27 & 81 & 81 & 14 & 13 & 13 \\
\hline Purchased corn grain, $t$ of $\mathrm{DM}$ & 195 & 195 & 174 & 192 & 197 & 40 & 40 & 47 & 55 & 58 \\
\hline Purchased vitamins and minerals, $\mathrm{t}$ & 9.2 & 5.5 & 6.5 & 6.5 & 6.5 & 3.5 & 2.4 & 3.2 & 3.2 & 3.1 \\
\hline Milk produced, $\mathrm{kg} / \mathrm{yr}$ & 8,966 & 8,966 & 8,966 & 8,966 & 8,966 & 6,413 & 6,413 & 6,413 & 6,413 & 6,413 \\
\hline
\end{tabular}

${ }^{1}$ Baseline = current farming system; scenario 1 = precision diet formulation and delivery; scenario $2=$ scenario $1+$ increased grass productivity and a high-forage diet; scenario $3=$ scenario $2+50 \%$ corn land converted to grass; scenario $4=$ scenario $2+100 \%$ corn land converted to grass.

${ }^{2}$ Combined values for both grazed and harvested grass forage: for pasture alone, IFSM sets CP $=26 \%$ for spring and fall, and CP = $23 \%$ for spring; and NDF values for pasture start at $52 \%$ in spring, increase to $55 \%$ in the summer, and drop to $53 \%$ in the fall. 
Table 6. Integrated farm system model (IFSM)-predicted average daily diet composition of lactating cows for winter (November to March) and for nonwinter (April to October) for a typical year, for all scenarios simulated for R-farm and W-farm

\begin{tabular}{|c|c|c|c|c|c|c|c|c|c|c|}
\hline \multirow[b]{2}{*}{ Item } & \multicolumn{5}{|c|}{ R-farm (102 mature cows) } & \multicolumn{5}{|c|}{ W-farm (52 mature cows) } \\
\hline & Baseline $^{1}$ & Scenario 1 & Scenario 2 & Scenario 3 & Scenario 4 & Baseline $^{1}$ & Scenario 1 & Scenario 2 & Scenario 3 & Scenario 4 \\
\hline & & & & & - Nonwin & er feeds & & & & \\
\hline Forage portion of diet, $\%$ & 48 & 48 & 67 & 65 & 67 & 62 & 62 & 89 & 88 & 86 \\
\hline Grazed forage & 3.9 & 3.9 & 3.2 & 3.3 & 3.6 & 2.2 & 2.2 & 2.7 & 2.7 & 2.7 \\
\hline Grass and alfalfa silage & 2.8 & 2.8 & 6.3 & 7.0 & 7.8 & 3.6 & 3.6 & 6.7 & 7.2 & 7.7 \\
\hline Grass and alfalfa hay & 1.7 & 1.7 & 2.1 & 2.3 & 2.4 & 2.7 & 2.7 & 3.6 & 3.8 & 4.1 \\
\hline Corn silage & 1.7 & 1.7 & 2.3 & 1.1 & 0.0 & 2.1 & 2.1 & 2.1 & 1.1 & 0.0 \\
\hline Purchased corn grain & 6.5 & 6.5 & 5.6 & 6.1 & 5.5 & 1.5 & 1.5 & 1.6 & 1.7 & 2.0 \\
\hline Purchased protein supplement & 4.4 & 4.4 & 1.4 & 1.3 & 1.3 & 5.0 & 5.0 & 0.6 & 0.5 & 0.4 \\
\hline Total feed intake, $\mathrm{kg} / \mathrm{d}$ & 21 & 21 & 21 & 21 & 21 & 17 & 17 & 17 & 17 & 17 \\
\hline Forage portion of diet, $\%$ & 47 & 47 & 66 & 64 & 66 & 62 & 62 & 87 & 85 & 83 \\
\hline Grazed forage & 0 & 0 & 0 & 0 & 0 & 0 & 0 & 0 & 0 & 0 \\
\hline Grass and alfalfa silage & 4.3 & 4.3 & 7.9 & 8.7 & 9.9 & 4.5 & 4.5 & 7.8 & 8.5 & 9.0 \\
\hline Grass and alfalfa hay & 2.6 & 2.6 & 2.6 & 2.8 & 3.1 & 3.1 & 3.1 & 4.2 & 4.5 & 4.8 \\
\hline Corn silage & 2.7 & 2.7 & 2.9 & 1.4 & 0.0 & 2.6 & 2.6 & 2.6 & 1.3 & 0.0 \\
\hline Purchased corn grain & 6.5 & 6.5 & 5.3 & 5.8 & 5.2 & 1.4 & 1.4 & 1.6 & 1.9 & 2.2 \\
\hline Purchased protein supplement & 4.2 & 4.2 & 1.7 & 1.6 & 1.7 & 5.0 & 5.0 & 0.6 & 0.6 & 0.5 \\
\hline Total feed intake, $\mathrm{kg} / \mathrm{d}$ & 20 & 20 & 20 & 20 & 20 & 17 & 17 & 17 & 17 & 17 \\
\hline
\end{tabular}

${ }^{1}$ Baseline = current farming system; scenario 1 = precision diet formulation and delivery; scenario 2 = scenario $1+$ increased grass productivity and a high-forage diet; scenario $3=$ scenario $2+50 \%$ corn land converted to grass; scenario $4=$ scenario $2+100 \%$ corn land converted to grass. 
Table 7. Integrated farm system model (IFSM)-simulated outputs for a baseline scenario and changes in simulated outputs of alternative precision feed management (PFM) farm planning scenarios from the baseline scenario for the R-farm

\begin{tabular}{|c|c|c|c|c|c|}
\hline \multirow[b]{2}{*}{ IFSM model output } & \multirow[b]{2}{*}{ Baseline $^{1}$} & \multicolumn{4}{|c|}{ Change in value ${ }^{2}$ as compared with baseline scenario } \\
\hline & & Scenario 1 & Scenario 2 & Scenario 3 & Scenario 4 \\
\hline $\mathrm{P}$ imported, $\mathrm{kg} / \mathrm{ha}$ & 19.6 & -5.8 & -9.6 & -9.6 & -9.8 \\
\hline In fertilizer, $\mathrm{kg} / \mathrm{ha}$ & 0.7 & 0 & 0 & -0.3 & -0.7 \\
\hline In precipitation, $\mathrm{kg} / \mathrm{ha}$ & 0.5 & 0 & 0 & 0 & 0 \\
\hline In feed, $\mathrm{kg} / \mathrm{ha}$ & 18.4 & -5.8 & -9.6 & -9.3 & -9.1 \\
\hline $\mathrm{P}$ exported, $\mathrm{kg} / \mathrm{ha}$ & 10 & 0 & 0 & 0 & 0 \\
\hline In milk and animal, $\mathrm{kg} / \mathrm{ha}$ & 8.9 & 0 & 0 & 0 & 0 \\
\hline In feed, kg/ha & 1.1 & 0 & 0 & 0 & 0 \\
\hline $\mathrm{P}$ balance, $\mathrm{kg} / \mathrm{ha}$ & 9.6 & -5.8 & -9.6 & -9.6 & -9.8 \\
\hline Manure produced, $\mathrm{t}$ of $\mathrm{DM}$ & 275 & 0 & 9 & 8 & 1 \\
\hline $\mathrm{P}$ in manure, $\mathrm{kg}$ & 1,961 & -490 & -454 & -460 & -497 \\
\hline Erosion sediment loss, $\mathrm{kg} / \mathrm{ha}$ & 5,750 & 0 & -131 & $-2,187$ & $-3,176$ \\
\hline Soluble P loss, kg /ha & 0.53 & -0.07 & -0.09 & -0.10 & -0.12 \\
\hline Sediment-bound $\mathrm{P}$ loss, $\mathrm{kg} / \mathrm{ha}$ & 1.76 & -0.03 & -0.09 & -0.54 & -0.78 \\
\hline $\mathrm{N}$ imported, kg/ha & 155 & 0 & 36 & 43 & 50 \\
\hline $\mathrm{N}$ exported, kg/ha & 59 & 0 & 1 & 4 & 5 \\
\hline $\mathrm{N}$ leached, $\mathrm{kg} / \mathrm{ha}$ & 29 & 0 & 5 & 6 & 7 \\
\hline \multirow[t]{2}{*}{$\mathrm{N}$ concentration in leachate, $\mathrm{mg} / \mathrm{L}$} & 6 & 0 & 1.9 & 2.2 & 2.3 \\
\hline & \multicolumn{5}{|c|}{ Cost and return expressed per mature cow, $\$ /$ cow } \\
\hline Milk and animal income & 3,318 & 0 & 0 & 0 & 0 \\
\hline Total production cost & 2,880 & -20 & -237 & -235 & -253 \\
\hline Machinery cost & 596 & 0 & 10 & -19 & -45 \\
\hline Fuel, electric, and labor cost & 279 & 0 & 41 & 50 & 57 \\
\hline Storage facilities cost & 56 & 0 & -10 & -6 & -3 \\
\hline Seed, fertilizer, and chemical cost & 74 & 0 & 57 & 54 & 55 \\
\hline Land rental and property tax & 61 & 0 & 0 & 0 & 0 \\
\hline Purchased feed and bedding cost & 728 & -20 & -335 & -316 & -318 \\
\hline Animal facilities and other expenses & 1,087 & 0 & 0 & 0 & 0 \\
\hline Farm net return & 438 & 20 & 237 & 235 & 253 \\
\hline Standard deviation in net return & 44 & 0 & 3 & 4 & 4 \\
\hline
\end{tabular}

\footnotetext{
${ }^{1}$ Baseline = current farming system; scenario 1 = precision diet formulation and delivery; scenario $2=$ scenario $1+$ increased grass productivity and a high-forage diet; scenario $3=$ scenario $2+50 \%$ corn land converted to grass; scenario $4=$ scenario $2+100 \%$ corn land converted to grass.

${ }^{2}$ Change in value $=$ alternative scenario value - baseline scenario value .

${ }^{3}$ Total concentrate includes grain, protein, vitamins, and mineral $\mathrm{P}$.
}

18 percentage points and the W-farm increasing 24 percentage points.

Because total DMI for each herd was held constant as part of the assumptions across all scenarios, shifts in forage as percentage of total ration DM were accomplished by increasing the amount of forage fed, and decreasing the amount of purchased grain fed. Across all high-forage scenarios (scenarios 2 to 4 ) and across winter and nonwinter feeds, model predicted forage intakes increased $3.5 \mathrm{~kg} / \mathrm{d}$ per cow on the R-farm and 4.1 $\mathrm{kg} / \mathrm{d}$ per cow on the $\mathrm{W}$-farm.

Under high-forage scenarios (scenarios 2 to 4 ) both decreases in purchased supplements and $\mathrm{P}$ density of the total diets were responsible for the predicted decreases in $\mathrm{P}$ imports and balances on both farms. Decreases in manure $\mathrm{P}$ excretions (24 and $21 \%$, respectively, for R-farm and W-farm, Tables 7 and 8) are largely attributable to the change in ration $\mathrm{P}$ density, which was adjusted through manipulation of mineral $\mathrm{P}$ supplementation rates on both farms. A similar strat- egy for manipulating ration $\mathrm{P}$ density was implemented on farms in the Cannonsville Reservoir basin in the study of Cerosaletti et al. (2004), yielding a 33\% reduction in manure $\mathrm{P}$ excretion.

For the R- and the W-farms, increased forage feeding rates resulted in a decrease in the amount of purchased protein supplement required in the diet (Table 6). This was possible due to the increase in hay crop silage (grass and alfalfa) fed, which had relatively high protein content compared with the corn silage DM it replaced in the diets in scenarios 3 and 4 on both farms. Decreasing the amount of corn silage in the diet did not increase manure $\mathrm{P}$ excretion (Tables 7 and 8), even though corn silage typically has a lower $\mathrm{P}$ content than grass forage (Cerosaletti et al., 2004). This indicates that hay crop forage $\mathrm{P}$ content modeled in this study was not a limiting factor in balancing the rations for the target lower $\mathrm{P}$ densities presented in Table 2. High hay crop forage $\mathrm{P}$ content could pose a problem in reducing ration $\mathrm{P}$ content (Cerosaletti et al., 2004), especially when an 
Table 8. Integrated farm system model (IFSM)-simulated outputs for a baseline scenario and changes in simulated outputs of alternative precision feed management (PFM) farm planning scenarios from the baseline scenario for the $\mathrm{W}$-farm

\begin{tabular}{|c|c|c|c|c|c|}
\hline \multirow[b]{2}{*}{ IFSM model output } & \multirow[b]{2}{*}{ Baseline $^{1}$} & \multicolumn{4}{|c|}{ Change in value ${ }^{2}$ as compared with baseline scenario } \\
\hline & & Scenario 1 & Scenario 2 & Scenario 3 & Scenario 4 \\
\hline $\mathrm{P}$ imported, kg/ha & 9.9 & -2.3 & -4.7 & -4.8 & -5.2 \\
\hline In fertilizer, $\mathrm{kg} / \mathrm{ha}$ & 0.6 & 0 & 0 & -0.3 & -0.6 \\
\hline In precipitation, $\mathrm{kg} / \mathrm{ha}$ & 0.5 & 0 & 0 & 0 & 0 \\
\hline In feed, $\mathrm{kg} / \mathrm{ha}$ & 9.2 & -2.3 & -4.7 & -4.5 & -4.6 \\
\hline $\mathrm{P}$ exported, $\mathrm{kg} / \mathrm{ha}$ & 4.6 & 0 & 0.1 & 0.1 & 0.1 \\
\hline In milk and animal, $\mathrm{kg} / \mathrm{ha}$ & 4.6 & 0 & 0.1 & 0.1 & 0.1 \\
\hline In feed, $\mathrm{kg} / \mathrm{ha}$ & 0 & 0 & 0 & 0 & 0 \\
\hline $\mathrm{P}$ balance, $\mathrm{kg} / \mathrm{ha}$ & 5.3 & -2.3 & -4.8 & -4.9 & -5.3 \\
\hline Manure produced, $\mathrm{t}$ of $\mathrm{DM}$ & 139 & 0 & 4 & 3 & 3 \\
\hline $\mathrm{P}$ in manure, $\mathrm{kg}$ & 858 & -145 & -187 & -185 & -191 \\
\hline Erosion sediment loss, $\mathrm{kg} / \mathrm{ha}$ & 3,844 & 0 & -46 & -829 & -1511 \\
\hline Soluble P loss, $\mathrm{kg} / \mathrm{ha}$ & 0.46 & -0.08 & -0.08 & -0.1 & -0.13 \\
\hline Sediment-bound P loss, kg/ha & 1.40 & -0.01 & -0.05 & -0.26 & -0.46 \\
\hline $\mathrm{N}$ imported, $\mathrm{kg} / \mathrm{ha}$ & 136 & 0 & 47 & 52 & 58 \\
\hline $\mathrm{N}$ exported, $\mathrm{kg} / \mathrm{ha}$ & 27 & 0 & 0 & 1 & 1 \\
\hline $\mathrm{N}$ leached, $\mathrm{kg} / \mathrm{ha}$ & 25 & 0 & 7 & 5 & 4 \\
\hline \multirow[t]{2}{*}{$\mathrm{N}$ concentration in leachate, $\mathrm{mg} / \mathrm{L}$} & 6.5 & 0 & 1.5 & 1 & 0 \\
\hline & \multicolumn{5}{|c|}{ — Cost and return expressed per mature cow, $\$ /$ cow } \\
\hline Milk and animal income & 2,453 & 0 & 0 & 0 & 0 \\
\hline Total production cost & 2,345 & -12 & -162 & -153 & -186 \\
\hline Machinery cost & 566 & 0 & 21 & 21 & -4 \\
\hline Fuel, electric and labor cost & 224 & 0 & 32 & 31 & 29 \\
\hline Storage facilities cost & 33 & 0 & 6 & 5 & 3 \\
\hline Seed, fertilizer, and chemical cost & 138 & 0 & 75 & 72 & 66 \\
\hline Land rental and property tax & 104 & 0 & 0 & 0 & 0 \\
\hline Purchased feed and bedding cost & 569 & -12 & -296 & -281 & -279 \\
\hline Animal facilities and other expenses & 712 & 0 & 0 & 0 & 0 \\
\hline Farm net return & 108 & 12 & 162 & 153 & 186 \\
\hline Standard deviation in net return & 26 & -9 & 4 & -14 & 0 \\
\hline
\end{tabular}

\footnotetext{
${ }^{1}$ Baseline $=$ current farming system; scenario $1=$ precision diet formulation and delivery; scenario $2=$ scenario $1+$ increased grass productivity and a high-forage diet; scenario $3=$ scenario $2+50 \%$ corn land converted to grass; scenario $4=$ scenario $2+100 \%$ corn land converted to grass.

${ }^{2}$ Change in value $=$ alternative scenario value - baseline scenario value

${ }^{3}$ Total concentrate includes grain, protein, vitamins, and mineral $\mathrm{P}$.
}

additional precision feeding goal is to increase the amount of such forage in a diet.

Although intake of purchased protein supplements was reduced dramatically in the diets of both herds as higher forage diets were simulated, purchased corn grain was not (Table 6 ). In the $\mathrm{W}$-farm simulations, corn grain feeding levels increased $0.4 \mathrm{~kg} / \mathrm{d}$ per cow compared with baseline ration levels, as forage feeding levels increased. This increase was due to the need for more ruminally available carbohydrate by rumen microbes in order for them to utilize the greater amount of ruminally available $\mathrm{N}$ provided by the increased hay crop silage intake. Additionally, the reduction of corn silage in the diet reduces the contribution of carbohydrate from that forage, requiring more starch purchased in the form of corn grain. In the R-farm simulations, purchased corn grain levels are reduced $0.96 \mathrm{~kg} / \mathrm{d}$ per cow as forage feeding levels are increased. Although this simulated decrease was not anticipated, it may be due to the relatively high level of corn meal that this herd was already feeding in the baseline diets, 4.5 times more than fed on the W-farm in the baseline scenario.

Although in these simulations the total DMI was not allowed to increase in these simulations, another possible approach with either farm would have been to allow the cows to eat more total DM by increasing forage intake, and reducing or holding total grain intake constant (or reducing it less than in this study) and allowing the cows to produce more milk from the increased nutrient intake. This alternative scenario is plausible because improved forage quality may result in lower forage NDF content and allow the cow to consume more DMI. Such an alternative scenario would likely result in less reduction to farm $\mathrm{P}$ imports, less reduction in farm $\mathrm{P}$ mass balance, and potentially not as great a reduction in manure $\mathrm{P}$ excretions than simulated because an additional $22 \%$ reduction in farm $\mathrm{P}$ imports per ha was achieved by reducing grain feeding rates under improved forage production and high forage feeding scenarios (Tables 7 and 8). Although allowing the 

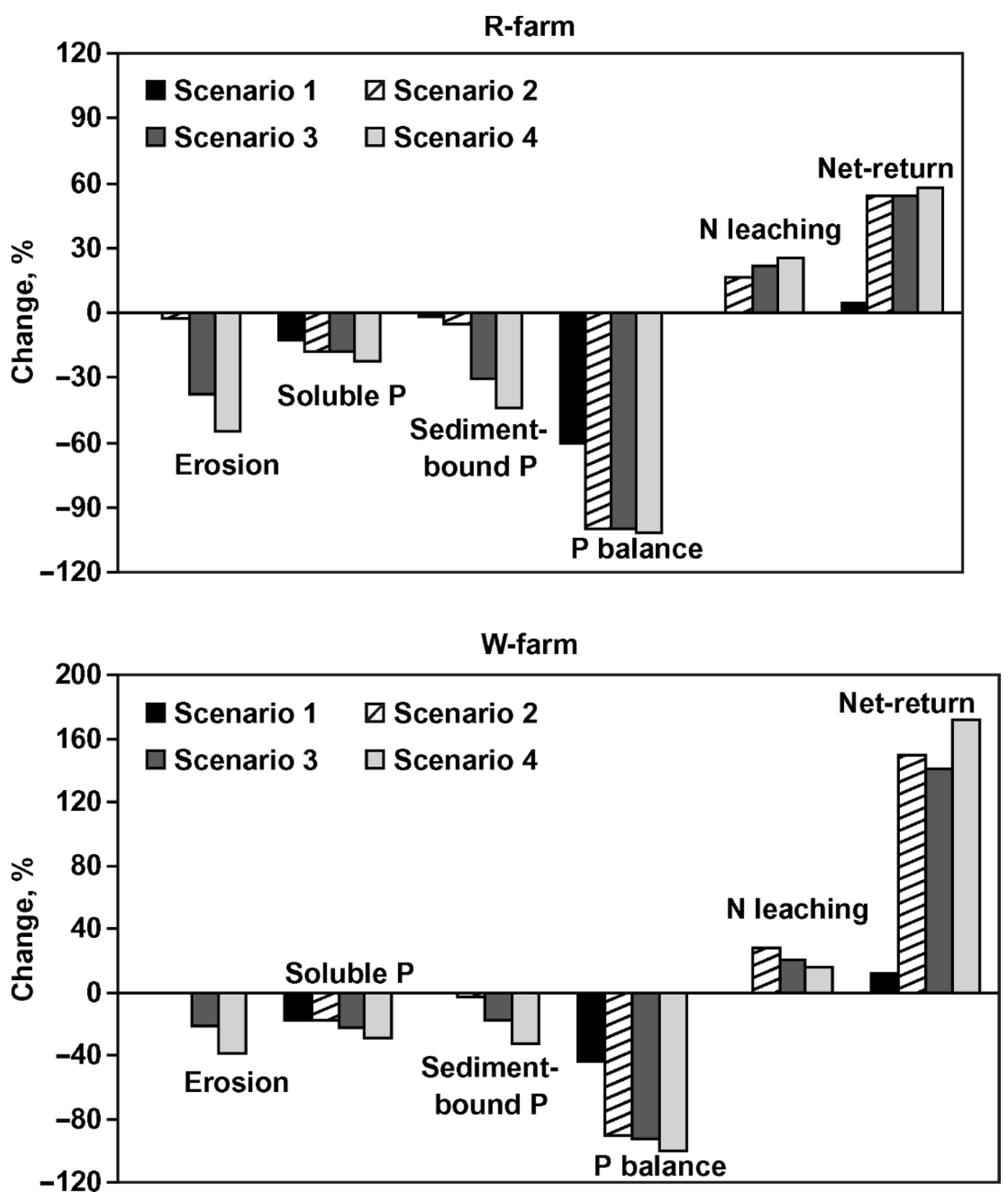

Figure 2. Percentage change of integrated farm system model (IFSM)-simulated outputs for precision feed management (PFM)-based farm strategies relative to baseline scenario. Scenario $1=$ precision diet formulation and delivery; scenario $2=$ scenario $1+$ increased grass productivity and a high-forage diet; scenario $3=$ scenario $2+50 \%$ corn land converted to grass; scenario $4=$ scenario $2+100 \%$ corn land converted to grass; scenario $5=$ scenario $4+$ extra forage production for sale.

cows to produce more milk in an alternative scenario would increase farm $\mathrm{P}$ exports, it would not likely be enough to offset the higher level grain feeding because milk $\mathrm{P}$ content is considerably less than grain $\mathrm{P}$ content.

P-Related Environmental Impacts. Reducing the dietary P level to NRC (2001) recommendations resulted in the need to purchase less mineral $\mathrm{P}$ supplement, with subsequent reductions in the amounts of nutrient $\mathrm{P}$ imported to the farms, and consequently reductions in farm $\mathrm{P}$ imbalances. The predicted farmlevel $\mathrm{P}$ balance was reduced by 5.8 and $2.3 \mathrm{~kg} / \mathrm{ha}$ for the $\mathrm{R}$-farm and the W-farm, respectively, under Scenario 1 (Tables 7 and 8). These reductions were equivalent to 60 and $43 \%$, for $\mathrm{R}$ - and $\mathrm{W}$-farms, respectively, as compared with the baseline conditions (Figure 2). These results are comparable to the $49 \%$ reduction in mass $\mathrm{P}$ balance 
obtained by Cerosaletti et al. (2004) for 2 CRW farms in which feed $\mathrm{P}$ intake was decreased by $25 \%$.

As the field-applied manure produced from cows that fed a reduced-P diet (Scenario 1) contained a lower concentration of $\mathrm{P}$ than that of the baseline farm scenario, simulated off-farm $\mathrm{P}$ loss, mainly soluble $\mathrm{P}$ loss with runoff, was reduced. The off-farm soluble P loss reductions predicted by IFSM were $0.07 \mathrm{~kg} / \mathrm{ha}$ for the $\mathrm{R}$-farm and $0.08 \mathrm{~kg} / \mathrm{ha}$ for the $\mathrm{W}$-farm (Tables 7 and 8 ). These represent 13 and $18 \%$ reductions, for $\mathrm{R}$ - and $\mathrm{W}$-farms respectively, in off-farm soluble $\mathrm{P}$ losses due to reduced dietary $\mathrm{P}$ level (Figure 2). Similar results were shown by Ebeling et al. (2002); when dairy manure from 2 dietary P levels $(0.49$ and $0.31 \% \mathrm{P})$ was surface applied, soluble P loss with runoff was lower with the manure from cows being fed a lower P diet. Predicted losses of sediment-bound $\mathrm{P}$ from the R-and W-farms were reduced by 0.03 and $0.01 \mathrm{~kg} / \mathrm{ha}$, respectively, compared with baseline conditions (Tables 7 and 8).

Reduced feeding of $\mathrm{P}$ in the diets, in conjunction with increasing the productivity of grass forages and increasing the proportion of forage in the diet, resulted in further reductions in farm P imbalance. Consequently, the scenario $2 \mathrm{P}$ balances were reduced by $9.6 \mathrm{~kg} / \mathrm{ha}$ for the R-farm and $4.8 \mathrm{~kg} / \mathrm{ha}$ for the $\mathrm{W}$-farm compared with the baseline (Tables 7 and 8). Compared with scenario 1 , scenario 2 reduced the $\mathrm{P}$ balance an additional $3.8 \mathrm{~kg} / \mathrm{ha}$ for the $\mathrm{R}$-farm and $2.5 \mathrm{~kg} / \mathrm{ha}$ for the $\mathrm{W}$-farm. Scenario 2 incrementally reduced the overall $\mathrm{P}$ balances of the farms by 40 and $48 \%$ over scenario 1 for the Rand W-farms, respectively (Figure 2). Predicted reductions of sediment-bound and soluble P losses off-farm for scenario 2 were minimal compared with scenario 1 .

Increasing the productivity of grass forages and increasing the proportion of forage in the diet combined with reduced feeding of $\mathrm{P}$ in the diet demonstrated that better balancing of $\mathrm{P}$ inputs and outputs could be maintained for a farm enterprise. The set of conditions assumed, including forage production, forage quality, forage feeding level, and feed mixes, suggests that achieving a zero $\mathrm{P}$ balance is possible as indicated in the simulation result of scenario 2. Predictions were done for a 25-yr period; hence results are expected to represent a variety of weather conditions. Nonetheless, uncontrollable extreme conditions, such as weather, that affect harvesting and feed storage and, in turn, affect forage production and quality, may hinder the production of the required forage amounts and quality to achieve a zero $\mathrm{P}$ balance. Additionally, farmers may choose to increase milk production with improved forage instead of holding it constant, thereby not reducing the grain supplement feeding rate as much as was done in scenario 2. This choice may increase net returns for the farmers, but it would result in a continued $\mathrm{P}$ mass imbalance (accumulation). Hence, findings and insights developed in this study may be utilized as a benchmark for attaining forage production and herd feed mix conditions that control P imbalances.

By converting corn land use to grass, erosion and associated P losses were reduced. Still, there was no appreciable change in the farm $\mathrm{P}$ balance due to this land use conversion. Compared with the baseline scenario, for instance, the reduction in farm $\mathrm{P}$ balance for the R-farm under both scenarios 2 and 3 was $9.6 \mathrm{~kg} /$ ha. Similarly, the reduction in farm $\mathrm{P}$ balances for the W-farm was $4.9 \mathrm{~kg} / \mathrm{ha}$ for scenario 3 and $4.8 \mathrm{~kg} / \mathrm{ha}$ for scenario 2. For scenario 4 , the reductions in farm $\mathrm{P}$ balances compared with the baseline were 9.8 and 5.3 $\mathrm{kg} / \mathrm{ha}$ for the R-farm and W-farm, respectively. These small changes in $\mathrm{P}$ balance were due to the increased feed purchases required to offset energy lost from the diet with reduced feeding of corn silage. Moreover, under scenarios 3 and 4 , the farms reduced farm $\mathrm{P}$ inputs through reduced use of starter $P$ fertilizer that would have been applied to corn crops. A study by Rotz et al. (2002) reported a minimal effect of cropping changes on the farm $P$ balance.

The reduction of erosion and associated sedimentbound $\mathrm{P}$ losses realized by switching corn fields to grass was directly proportional to the area of corn converted to grass. For example, under scenario 3 for the R-farm, losses of sediment, soluble $\mathrm{P}$, and sediment-bound $\mathrm{P}$ in runoff were reduced by 38,18 , and $31 \%$, respectively, compared with the baseline scenario (Figure 2). For the W-farm, losses of sediment via erosion, soluble P, and sediment-bound $\mathrm{P}$ in runoff were reduced by 22,22 , and $18 \%$, respectively, compared with the baseline scenario (Figure 2). Under scenario 4, the reductions in sediment, soluble $\mathrm{P}$, and sediment-bound $\mathrm{P}$ were 55,23 , and $44 \%$, respectively, for the R-farm compared with the baseline scenario, and 40,29 , and $32 \%$, respectively, for the W-farm. The model predicted that every 1 ha of corn converted to grass reduced annual sediment-bound P loss by $9.3 \mathrm{~kg} / \mathrm{ha}$ for the R-farm and $5.8 \mathrm{~kg} / \mathrm{ha}$ for the W-farm. A modeling study using SWAT (Gitau, 2003) reported $6.5 \mathrm{~kg} / \mathrm{ha}$ sediment-bound $\mathrm{P}$ loss from corn land use in the Town Brook Watershed. In total, the reductions in sediment and $P$ loss achieved by switching corn land use to grass may be very important to improving water quality, particularly if the converted corn fields are in close proximity to streams (Sharpley et al., 2001).

N-Related Environmental Impacts. For scenario 1 , there was no change in predicted $\mathrm{N}$ leaching losses and concentrations compared with the baseline because the scenario involved change only to the dietary $\mathrm{P}$ and resulting $\mathrm{P}$ concentration in manure. On the other hand, predicted $\mathrm{N}$ loss in leachate increased across the 
2 farms for scenarios in which additional $\mathrm{N}$ fertilizer was required to increase forage productivity (scenarios 2 to 4; Tables 7 and 8). For scenario 2, for example, predicted $\mathrm{N}$ loss in leachate increased by $5 \mathrm{~kg} / \mathrm{ha}$ for the R-farm and $7 \mathrm{~kg} / \mathrm{ha}$ for the $\mathrm{W}$-farm compared with the baseline (Tables 7 and 8). Also, predicted $\mathrm{N}$ leaching concentration increased by $1.9 \mathrm{mg} / \mathrm{L}$ for the R-farm and $1.5 \mathrm{mg} / \mathrm{L}$ for the W-farm compared with the baseline (Tables 7 and 8). Predicted $\mathrm{N}$ concentrations in leachate for all scenarios were below or a little higher than the 10 $\mathrm{mg} / \mathrm{L}$ maximum contaminant level for drinking water. These $\mathrm{N}$ concentration values represent off-field losses, not losses at the streams. Therefore, the magnitudes of these losses were not considered to pose a major concern to the environment. Nonetheless, the need for better management practices to better match $\mathrm{N}$ availability to crop needs to control N-leaching losses and increase efficiency of $\mathrm{N}$ use for all forage production levels is recognized.

Economic Impacts. In scenario 1, the reduction in desired feed $\mathrm{P}$ content and subsequent decrease in purchased mineral $\mathrm{P}$ supplements impacted both farms financially. The annual farm net-return (based on longterm averages) predicted by IFSM for Scenario 1 increased by $\$ 20 /$ cow for the R-farm and $\$ 12 /$ cow for the $\mathrm{W}$-farm (Tables 7 and 8). The result was equivalent to a farm-level net-return increase of $\$ 2,040$ for the Rfarm and $\$ 624$ for the $\mathrm{W}$-farm. Based on a $\$ 550 / \mathrm{t}$ price for vitamins and mineral $P$ supplement, these farm netreturns represent the money saved as a result of the 3.7 and $1.1 \mathrm{t}$ reduction in mineral supplements purchased for R- and W-farms, respectively.

When costs of $\mathrm{N}$ fertilizer and additional farm operations required to increase grass forage productivity are lower than the cost of feed supplements, the profit of the farm may increase. Based on the simulated results related to cost and net-returns, expenses of purchased fertilizer, fuel, machinery, storage, and labor were greater in scenario 2 than in the baseline scenario (+\$98/cow for R-farm, and $+\$ 134 /$ cow for the W-farm; Tables 7 and 8). Yet purchased feed and related costs for scenario 2 were much lower than in the baseline scenario ( $-\$ 335 /$ cow for R-farm, and $-\$ 296 /$ cow for $\mathrm{W}$ farm; Tables 7 and 8). Thus, an increase in annual farm net-returns of $\$ 237 /$ cow and $\$ 162 /$ cow was realized in scenario 2 for the R- and W-farms, respectively.

For scenarios 3 and 4, there were no straightforward findings as to how reductions in area of corn affected financial conditions of the farms. This was because 1) corn land use conversion to grass was applied to the already-redesigned farms, having increased forage production and utilization, and not to the baseline conditions, and 2) financial changes occurred in various aspects of the farm production system, such as costs of buying feeds along with fertilizer and crop production operating costs. Operating costs for producing corn are usually higher than those for grasses, but when the costs of purchased feed and fertilizer are higher than the money saved from reduced operational costs for grass production, the farms may not gain in profit. This was evident from the IFSM results for scenario 3 for both farms, where a reduction in farm net-return was predicted. Because more corn grain concentrates were purchased in scenario 3 than in scenario 2, the annual farm net-return in scenario 3 was decreased by $\$ 2 /$ cow for the R-farm and $\$ 9 /$ cow for the $\mathrm{W}$-farm, compared with the corresponding farm net-returns in scenario 2 (Tables 7 and 8). Nevertheless, the farm net-returns under scenario 3 were still greater than those in the baseline scenario and in scenario 1 . When all corn fields were switched to grass in scenario 4, IFSM-predicted farm net-returns increased for both farms. The increase was mainly due to reduced total cost of production attributed to the reduced cost of machinery. Machinery costs were lower in scenario 4 than in scenario 3 for both farms. With no corn production, the fixed costs of owning corn production equipment as well as operational costs were eliminated.

\section{CONCLUSIONS}

The IFSM enabled a comprehensive evaluation of alternative farm planning strategies prior to their implementation. Such model-based studies done on a farm-by-farm basis are useful in complementing farm planning efforts in exploring innovative farming systems that have the potential to maintain or increase farm profitability, and reducing nutrient imbalances and subsequent off-farm nutrient losses. If similar studies are expanded to multiple farms within a watershed, the findings could aid in incorporating the most critical level of land management, farm planning, into a watershed-based management planning. Results of this study show that PFM farm plans that include precision diet formulation and delivery, on-farm forage management and utilization, and land use management have great potential to benefit farms as well as the environment.

While this study focused on 2 farms, the model-based approach used is widely applicable, as is the methodology of representing alternative whole-farm system strategies to evaluate and quantify impacts of these strategies on milk production, farm profitability, and farm-level P flows and losses. Similar approaches can be applied to dairy farms throughout the northeastern United States where implementations of PFM strategies are of interest. Moreover, these results set a benchmark for potential benefits of PFM strategies, economic 
and environmentally. In summary, the methodology developed is helpful in assessing farm system options prior to their implementation.

\section{ACKNOWLEDGMENTS}

The authors would like to thank Dale Dewing, Cornell Cooperative Extension, Delaware County, NY, for his diligent contributions toward formulating the alternative farm scenarios and providing the detailed farm data needed for this study. We are thankful to the farmers for allowing their data to be used and to the Delaware County Soil and Water Conservation District and the Watershed Agricultural Council for facilitating data collection and use. Contributions were provided by the USDA Agricultural Research Service, Pasture Systems and Watershed Management Research Unit, University Park, PA.

\section{REFERENCES}

Andresen, J. A., G. Alagarswamy, C. A. Rotz, J. T. Ritchie, and A. W. Lebaron. 2001. Weather impacts on maize, soybean, and alfalfa production in the Great Lakes Region 1895-1996. Agron. J. 93:1059-1070.

Cerosaletti, P. E., D. G. Fox, and L. E. Chase. 2004. Phosphorus reduction through precision feeding of dairy cattle. J. Dairy Sci. 87:2314-2323.

Cerosaletti, P. E., D. G. Fox, L. E. Chase, A. N. Pell, and W. A. Knoblauch. 1998. Application of the Cornell Net Carbohydrate and Protein System on a pasture based dairy farm. Pages 197211 in Proc. Cornell Nutr. Conf. Feed Manufacturers, Cornell Univ., Ithaca, NY.

Cherney, J. H., D. J. R. Cherney, and M. D. Casler. 2003. Low intensity harvest management of reed canarygrass. Agron. J. 93:418-428.

Delaware County Watershed Affairs. 2002. Delaware County Action Plan DCAP II for watershed protection and economic vitality. Delaware County Dept. Watershed Affairs, Delhi, NY.

Dou, Z., J. D. Ferguson, J. Fiorini, J. D. Toth, S. M. Alexander, L. E. Chase, C. M. Ryan, K. F. Knowlton, R. A. Kohn, A. B. Peterson, J. T. Sims, and Z. Wu. 2003. Phosphorus feeding levels and critical control points on dairy farms. J. Dairy Sci. 86:3787-3795.

Ebeling, A. M., L. G. Bundy, T. W. Andraski, and J. M. Powell. 2002. Dairy diet phosphorus effects on phosphorus losses in runoff from land-applied manure. Soil Sci. Am. J. 66:284-291.

Gitau, M. W. 2003. A quantitative assessment of BMP effectiveness for phosphorus pollution control: The Town Brook Watershed, NY. PhD Diss. Pennsylvania State Univ., University Park.

Gitau, M. W., and W. J. Gburek. 2005. Best Management Practice effects for phosphorus control on a Dairy Farm: The Cannonsville Reservoir Watershed, New York. ASAE Paper No. 052046. ASAE, St. Joseph, MI.
Jones, C. A., C. V. Cole, A. N. Sharpley, and J. R. Williams. 1984. A simplified soil and plant phosphorus model: I. Documentation. Soil Sci. Am. J. 48:800-805.

Ketterings, Q. M., J. Kahabka, and W. S. Reid. 2005. Trends in phosphorus fertility of New York agricultural land. J. Soil Water Cons. 59:10-20.

Klausner, S. D., S. Telega, and N. Leonard. 1997. Estimating a mass nutrient balance. Northeast Regional Agric. Eng. Serv., Ithaca, NY.

Knoblauch, W. A., L. D. Putnam, M. Kiraly, J. J. Walsh, S. E. Hadcock, and L. Hulle. 2005. Dairy farm business summary: Southeastern New York Region 2004. Dep. Appl. Econ. Manage., College of Agriculture and Life Sciences, Cornell Univ., Ithaca, NY.

Lounsbury, D. G. 2001. Cannonsville GIS LIB. New York City Department of Environmental Protection. Kingston, NY.

National Research Council. 2001. Nutrient Requirements of Dairy Cattle. 7th ed. Natl. Acad. Press, Washington, DC.

Neitsch, S. L., J. G. Arnold, J. R. Kiniry, J. R. Williams, and K. W. King. 2002. Soil and Water Assessment Tool 2000: Theoretical documentation. Texas Water Resources Institute, College Station, TX. http://www.brc.tamus.edu/swat/doc.html Accessed Feb. $13,2007$.

Rotz, C. A., and C. U. Coiner. 2006. Integrated Farm System Model (IFSM): Reference manual version 2.0. USDA Agricultural Research Service, University Park, PA. http://www.ars.usda.gov/ Main/docs.htm?docid=8519 Accessed Feb. 13, 2007.

Rotz, C. A., D. R. Mertens, D. R. Buckmaster, M. S. Allens, and J. H. Harrison. 1999. A dairy herd model for use in whole farm simulations. J. Dairy Sci. 82:2826-2840.

Rotz, C. A., A. N. Sharpley, L. D. Shatter, W. J. Gburek, and M. A. Sanderson. 2002. Production and feeding strategies for phosphorus management on dairy farms. J. Dairy Sci. 85:3142-3153.

Sedorovich, D. M., C. A. Rotz, and P. A. Vadas. 2005. Predicting management effects on phosphorus loss from farming systems. ASAE paper No. 0530053. ASAE, St. Joseph, MI.

Sharpley, A. N., R. W. McDowell, and P. J. A. Kleinman. 2001. Phosphorus loss from land and water: Integrating agricultural and environmental management. Plant Soil 237:287-307.

Soder, K. J., and C. A. Rotz. 2001. Economic and environmental impact of four levels of concentrate supplementation in grazing dairy herds. J. Dairy Sci. 84:2560-2572.

Tolson, B. A., and C. A. Shoemaker. 2004. Watershed modeling of the Cannonsville Basin using SWAT2000 for the Cannonsville Reservoir. Version 1.0. Technical Report, School of Civil and Environmental Eng., Cornell Univ., Ithaca, NY.

USDA. 2002 Census of Agriculture. USDA National Agricultural Statistics Service, Washington, DC. http://www.nass.usda.gov/ Census_of_Agriculture Accessed Feb. 13, 2007.

USDA. 2005. New York crop data 2002-2005. National Agricultural Statistics Database. USDA National Agricultural Statistics Service, Washington, DC http://www.nass.usda.gov/ Statistics_by_State/New_York/index.asp Accessed Feb. 13, 2007.

Walter, M. T., and M. F. Walter. 1999. The New York Watershed Agricultural Program (WAP): a model for comprehensive planning for water quality and agricultural economic viability. Water Resource Impact 1:5-8.

Wang, S. J., S. G. Fox, D. J. R. Cherney, S. D. Klausner, and D. R. Bouldin. 1999. Impact of dairy farming on well water nitrate level and soil content of phosphorus and potassium. J. Dairy Sci. 82:2164-2169. 